\title{
METHODOLOGICAL ISSUES INVOLVED IN CONDUCTING QUALITATIVE RE- SEARCH ON SUPPORT FOR NURSES DIRECTLY INVOLVED WITH WOMEN WHO CHOSE TO TERMINATE THEIR PREGNANCY
}

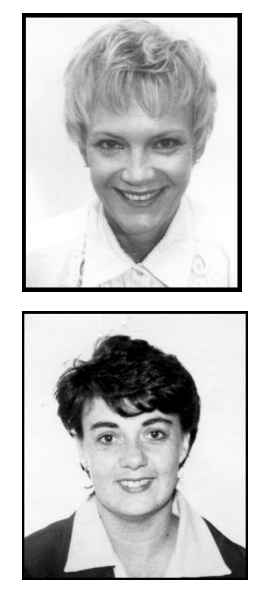

\author{
Antoinette Gmeiner \\ DCur (Psychiatric Nursing) \\ Department of Nursing Science, Rand Afrikaans University \\ Sandra van Wyk \\ DCur (Psychiatric Nursing) \\ Department of Nursing Science, Rand Afrikaans University \\ Marie Poggenpoel \\ RN, PhD, Professor: Nursing Science \\ Department of Nursing Science, Rand Afrikaans University \\ Chris Myburgh \\ MEd, BSc (Honn), MComm \& DEd, Professor: Education Sciences \\ Department of Educational Sciences, Rand Afrikaans University
}

\begin{abstract}
The purpose of this article is to describe the methodological issues involved in conducting qualitative research to explore and describe nurses' experience of being directly involved with termination of pregnancies and developing guidelines for support for these nurses. The article points out the sensitivity and responsibility that researchers must have when engaging in qualitative research of this nature. While conducting this research, several methodological challenges were identified. Four specific challenges identified will be addressed in this paper. These are: the issue of research versus therapeutic interviewing; adhering to specific research ethics, as this was a very sensitive topic of research; dissemination of research results to make it accessible to all nurses as well as the broader community; and the operationalisation of the support guidelines in practice for nurses in need of support.
\end{abstract}

\section{OPSOMMING}

Die doel van hierdie artikel is om die metodologiese vraagstukke te beskryf rondom die uitvoer van kwalitatiewe navorsing waar verpleegkundiges se ervaring van hul direkte betrokkenheid by terminasie van swangerskap verken en beskryf is. Die artikel beklemtoon die sensitiwiteit en verantwoordelikheid wat navorsers aan die dag moet lê wanneer kwalitatiewe navorsing van hierdie aard uitgevoer word. Tydens die uitvoering van hierdie navorsing is verskeie metodologiese uitdagings geïdentifiseer. Vier van hierdie spesifieke uitdagings wat geïdentifiseer is, word in hierdie artikel aangespreek, naamlik: die vraagstuk van navorsing versus terapeutiese onderhoudvoering; voldoening aan spesifieke navorsingsetiek, aangesien 
die onderwerp ' $n$ baie sensitiewe saak benader; disseminering van navorsingsresultate om dit toeganklik te maak vir alle verpleegkundiges, sowel as die breër gemeenskap; en die operasionalisering van die riglyne vir ondersteuning aan verpleegkundiges in die praktyk wat sodanige ondersteuning benodig.

\section{INTRODUCTION / BACKGROUND}

Since 1994, with the election of the Government of National Unity and the democratisation of the South African society, many changes have taken place that directly influence the health care delivery system in South Africa.

In the health care delivery system, women's health became a priority - specifically their reproductive choices. This entails that they may now choose to terminate a pregnancy as stated in the Freedom of Choice of Terminating Pregnancy Act (Act no. 92 of 1996). Since February 1997, more than 160000 legal terminations of pregnancy have been carried out (Badenhorst, 1999:13). The impact of this large number of terminations on the health care delivery system is enormous because very little provision has been made in the infrastructure to absorb this reality (Poggenpoel, Myburgh and Gmeiner, 1998:3). Well prepared professionals, clinics and finances are lacking.

The nursing profession, in particular, has been directly influenced by the impact of the legalisation on abortion. Large numbers of nurses refuse to be involved in the nursing of women who chose to terminate their pregnancies (Anon., 1997:6). In previous research conducted by Poggenpoel, Myburgh and Gmeiner (1998:2-8) it became clear that nurses were in favour of choosing to be directly involved in the execution of the procedure. It also became clear that these nurses needed multidimensional support to be able to cope with their daily tasks.

While conducting qualitative research to identify, explore and describe these nurses' experiences of being directly involved with termination of pregnancies to deduct guidelines for support for them, several methodological challenges were encountered by the researchers.

\section{PROBLEM STATEMENT}

In conducting qualitative research, especially when dealing with sensitive issues like women's freedom of choice to terminate their pregnancies, and nurses' experiences of direct involvement in the execution of the procedure, it is a challenge for the researchers to enter the field without any preconceived ideas to obtain a true reflection of the experiences of the nurses and to present this in an authentic and naturalistic manner.

Questions reflecting some of these methodological challenges are:

- What are the challenges involved in ensuring that researchers focus on the true experiences of the research participants and not getting in volved on a therapeutic level?

- How could researchers adhere to necessary ethical principles involved in qualitative research and at the same time obtain rich and saturated data?

- How could researchers disseminate results to grass roots level where it would be accessible to the wider community?

- What steps could researchers take to ensure that the research is functional and operationalised in practice?

\section{PURPOSE}

The aim of this article is to address the following identified methodological challenges:

- The distinction between a research interview and a therapeutic interview.

- Adhering to necessary research ethics such as privacy, confidentiality, anonymity and informed consent.

- The dissemination of research results.

- Ensuring that the research is functional (operationalisation of guidelines in practice). 


\section{CHALLENGE 1: RESEARCH (PHENOM- ENOLOGICAL) INTERVIEWS VERSUS THERAPEUTIC INTERVIEWS}

\section{Respecting the integrity of the stories told by the nurses}

In conducting phenomenological interviews researchers try to obtain the participants' real life experiences and stories. They enter the field using "bracketing" and "intuiting" to really "hear" the told and untold stories of real life experiences. It is not necessary for these researchers to be familiar with the world they are describing, but rather to reflect the stories as they are told. They comprehend, interpret and communicate these experiences to others (Morse, 1999). Frank (2000), with regard to the difficulties respondents have in telling their stories, reiterates the importance for the researcher to really listen to what their story is and to reflect these stories as they are told, and not to force it into the researchers' own frame of reference. "It should be the discourses of the respondents, and not fragmented to 'fit' within a research framework" ... In this regard, Frank warns that the literal integrity of a story could be sacrificed in order to generate the apparent integrity the scientist merits - the so-called discourses the scientist puts in place. ... "Standpoints have been conceptually shifted from that of the respondents back to the standpoint of the discourse locating the reading subject in the relations of ruling ... the stylistics of universality are preserved against the threat of fragmentation and disorder..." Frank (2000) warns that text can perpetuate the stylistics of universality and can rewrite local observations into extra local texts. The only allowable observation is that in which the local is read as an instance of the universal and traces of contingency are excluded. It's the discourse that perpetuates the relations of ruling.

Therefore, when imposing the stylistics of universality we lose individuality - refusing to see the real person, and that is what we should be aware of. We need to focus on the story of the respondent and to stay with the integrity of the respondent. Do not focus on "ruling relations" as the world prescribes it, or as we as psychiatric nurse practitioners would prescribe it.

\section{Distinction between a therapeutic and a re- search interview}

On another level, in dealing with such a sensitive and painful issue as termination of pregnancy, the researchers can be drawn into the pain and hurt of the experiences disclosed by the participants and the researchers can become involved on a therapeutic level. Morse (1999) states "most of you (researchers) will be able to recall large blocks of quotations and hear the participants' voice in your head many years after conducting a heart wrenching interview". This was also the researchers' individual experience and they still reflect on many of the stories they heard, such as: "There are times that I really need a break because it is emotionally exhausting ... the patient tells you all their problems and in the end you end up saying: "Oh My God, why do I have to do this?" and "One day I was standing at the sink crying my heart out. I said: "Lanny, my God, are we going to hell?" He was standing there, sweating and shaking, and said to me ... "Well, if we are, I'll be there first waiting on уои..."

Not only did the researchers experience internal discomfort in listening to these painful stories, but the nurse participants also experienced discomfort.

Nurse participants experienced reliving their own personal trauma while sharing their experiences. They utilised psychological defence mechanisms as a shield of protection against their own emotional pain and they described value conflicts and emotional fatigue in the whole process of being directly involved with termination of pregnancy. This was evidenced by the following quotations: "Hearing all of their stories makes me feel helpless, frightened and very tired and you don't know ... you are still confused..." and "You feel as though you can 
walk out, but you can't, you must be there and you must be supportive..." "I do NOT agree with her to have this termination ... it is against my religion, against all that I believe, that's why I think it is wrong".

Many times the researchers felt the need to comfort the nurse participants or even reflect their feelings of pain and anguish. It was very difficult for the researchers to stay in the "research" frame of mind and not to change to the "therapeutic" frame of mind, as they are also professional therapists who deal with patients in a therapeutic manner on a daily basis.

Frank (2000) states that research can create more suffering for participants and many of them relive their pain and trauma and therefore find it difficult to engage with interviewers. They used initial silence, which researchers could not really understand, but as Frank (2000) clearly explains ... "suffering prohibits talking - it quietens the voice of anguish and pain ... we will tell them to talk and communicate as this will help, but the suffering causes silence. Suffering and pain is what could NOT be said, what words could never convey what really is felt..."

Levinas (in Frank, 2000) verbalises the importance of sitting in silence with a person for a long time before even trying to understand his/her suffering ... rapport ... but this is often not how researchers see it. Levinas talks about the others' situation ... the unknowable of the others' suffering and autonomy. Levinas absolutely reiterates the responsibility of the researcher towards this "other".

The research interviews for this study were therefore conducted in an environment of sensitivity, harmony and acceptance where the researchers let the nurses tell their stories while listening in an attentive manner without interrupting them (Kvale, 1996:147-151; Creswell, 1994:145). The researchers also allowed much more time for bonding be- forehand, which created a sense of rapport, which in turn allowed for openness so that participants could tell their stories as they really were. Throughout the process of interviewing, the researchers kept reminding themselves to adhere to principles of conducting research interviews, and not therapeutic, supportive interviews.

After the interviews, researchers provided the opportunity for nurse participants to have a debriefing session with a therapist they were referred to. Having resorted to this measure, the researchers have shifted the therapeutic needs of the participants to a formal situation thereby leaving the data uncontaminated. The researchers hereby also adhered to the ethical principles of not harming the individual physically or mentally. In conducting these research interviews, nurse participants were confronted with many of their own "forgotten" pain and trauma, as direct involvement with termination of pregnancy resulted in the reliving of own personal trauma and pain.

"I see what they go through and I relive it every day and I don't want them to go through it like I did". (This nurse was raped and ended up going for a back-street abortion, before legalisation of abortion in South Africa). Another nurse stated: "I have undergone a back-street abortion and I know what if feels like" and "I am sure I would have felt different if it was not that I went through this myself ... I think this is my greatest motivation for helping them..." (Gmeiner, Van Wyk, Poggenpoel \& Myburgh, 1999:30-34).

\section{The impact of phenomenological interviews on researchers}

Morse \& Mitcham (1970:36) and Morse, Mitcham \& Van der Steen (1998:52) describe the experience of shared pain or "compathy" when dealing with nurses caring for trauma patients, and in this research it was reflected in dealing with nurses directly involved with termination of pregnancies. 
The researchers experienced the feeling of compathy daily while conducting the research and had many reflective conversations around this. They, as research instruments, experienced psychological discomfort consciously as well as sub-consciously related to the pain, anger, frustration, exhaustion and emotional turmoil these nurse participants experienced. Morse and Field (1996:307-310) describe this process as reflexivity, self-awareness and an awareness of the interaction between the researcher and the participant. The researchers had to be aware of this to enable them to put aside their own feelings when analysing and discussing data. They also realised that the pain and anguish described by the participants could never really be understood, as it was never all revealed.

The researchers realised that the suffering/psychological discomfort experienced put them on the other side of life as it should be ... and nothing could bridge that separation. Frank (2000) states "suffering is the unspeakable as opposed to what can be spoken, and at the core of suffering is the sense that something is irreparably wrong with our lives and wrong is the negation of what could have been right...". The researchers recognised these feelings and reflected on this with each interview they had. In a way, it became a debriefing session for them, as they always had a reflecting conversation after completing an interview. They even reflected on their own lives, and why some feelings of pain, anger, frustration and immense tiredness were experienced. They also took field notes (Wilson, 1989:434-435) with every interview. All interviews were audiotaped and transcribed verbatim together with the field notes soon afterwards to avoid any possible influence of the researchers' own psychological discomfort.

\section{CHALLENGE 2: ADHERING TO THE NECESSARY RESEARCH ETHICS WHILE CONDUCTING QUALITATIVE RESEARCH}

The ethical measures adhered to during this re- search process are those set out by DENOSA (Democratic Nurses Association of South Africa, 1998:3-7) and included informed consent, confidentiality and anonymity, protection from harm (psychological) and providing feedback .

All the participants partaking in the research project were selected purposively according to set criteria (Burns \& Grove, 1993:209). Only those from who informed consent were obtained, were included in the sample. As this was a very sensitive research issue, care was taken to ensure all participants' anonymity and privacy while conducting the research. Participants repeatedly asked the researchers NOT to mention their names, however, expressed an urgent need for their stories to be told and heard.

Many of the nurses revealed negative experiences due to the fact that they were directly involved with termination of pregnancy procedures. Some nurses were victimised once it became known that they chose to work at clinics where pregnancies are being terminated. They were called "murderers" and "baby-killers" and they, as well as their families were victimised (Gmeiner, Van Wyk, Poggenpoel \& Myburgh, 1999:34-35).

As one nurse participant stated: "It affected my child's life months after... I can stand up on my own, but she cannot ... it were when everybody sees her they say ... 'Oh, your mum kills babies'!'

As a result of this nurses also avoid telling their families where they really work. Their secrecy was used as a shield of protection against victimisation and cruelty. "I tell them I work in a family planning clinic and I never explain further" and "... as family they take it as part of my job that I am working as a family planning nurse ... I do not really tell them what I do".

It was therefore of utmost importance for the success of the research, and to hear the participants' 
stories, that the researchers reassured the participants of confidentiality and their anonymity repeatedly during the interviews.

In order to ethically address the psychological pain, value conflicts and emotional turmoil voiced by the participants, the researchers ensured that all nurses involved in the research project had enough time during the interviews to ventilate their feelings and tell their stories in an atmosphere of warmth and acceptance. This enabled the researchers to ascertain the "true" stories, or at least, the closest proximity to the truth. Ensuring debriefing/support after the in-depth, phenomenological interviews, was necessary and this was done by referring all the participants to a professional counsellor, should the need arise, to ensure that participants were not harmed in a psychological way by reliving and "restorying" their experiences.

Ethically, it is very important to "hear" what the participants' stories are, to ascertain the "truth" and to then represent their voices in a truthful way, and not an interpretation of the researchers frame of reference. Frank (2000) reiterates the importance of research ethics and repeats that discourses should be those of the respondents and not fragmented bits to fit within a research framework. Although interviews and scripts are inductively derived from respondents themselves, researchers have the responsibility to analyse data/script as open as possible, to reflect the true story (told and untold) as the participant experienced it.

In a research study conducted by Smith (in Frank, 2000), she recalls her own experience during the process of data analysis ... "bits of the story was made to appear as instances validating the point that the researcher was trying to make ... the literal integrity of the story was sacrificed in order to generate the apparent integrity the researcher merited..."

\section{CHALLENGE 3: DISSEMINATION OF RESEARCH RESULTS TO GRASS ROOTS LEVEL}

Morse (1999) explains the difficulties that sometimes accompany the problem of dissemination of research results. The compathetic response can make it " too painful to know" (Morse \& Mitcham, 1997:36; Morse, Mitcham \& Van der Steen, 1998:56). In this project of listening to the painful experiences of nurses directly involved with termination of pregnancy, the researchers sometimes felt quite "stuck" because of the psychological pain and anguish shared with the respondents. They found it painful to analyse the data and could not understand their procrastination of the analysis of the data. It was a painful reminder of all the stories they heard every time they were confronted with the data. It was also difficult to write articles, as the researchers desperately wanted to write the "best" story to represent the participants' urgent call for help. During this whole process the researchers debriefed each other constantly and used "time-out" to be able to disseminate the results as clearly as possible. In the dissemination of the results the researchers also found that one cannot say everything as it is. Quotations can be given, but it cannot change the controversial situation (Poggenpoel \& Myburgh, 2000:4). Researchers have the responsibility to represent the voices of the nurses as they have told their stories and not their interpretations as researchers, thereof.

The participants in this research reiterated the importance of their stories to be heard, not only in accredited research journals, but where it will be accessible to the wider community. The researchers, therefore, submitted manuscripts to several newspapers and popular magazines in South Africa for the information to be available for the broader community. Morse (1999) agrees with this and states that too much of our research remains at the descriptive level and is not disseminated where it is the most needed. 


\section{CHALLENGE 4: OPERATIONAL- ISATION OF RESEARCH IN PRACTICE}

The researchers envisage the methodological assumptions as set out by Botes (1992:36) for this research. The functional approach states that the valid knowledge must be utilised by the application thereof in practice to improve practice.

Many of the participants in this research added to this by saying: "You academics do a lot of research and we always wonder what happens next ... you publish it in research journals for your own recognition, but what about us now? We desperately need the support!"

The researchers described a framework, deducted from the results of the interviews and a literature control for the support of nurses directly involved in termination of pregnancy (Gmeiner, Van Wyk, Poggenpoel \& Myburgh, 2000:4-7) and has also presented this at several conferences throughout South Africa.

The researchers believe that the implementation of a debriefing support group within the context where the research was conducted would make a vast difference to the experience and coping skills of these nurses. As described by Gmeiner, Van Wyk, Poggenpoel and Myburgh (1999:30-34) debriefing support groups would address issues of value conflict, the utilisation of psychological defence mechanisms as a way of coping with emotional pain, their "silence" and identity as women, mothers and nurses. The goal of the support groups would be to provide a context within which the nurses feel love for themselves, allow others to care for them and to be more reflective, and to search and clarify their own values. Empowerment is established through a constructive process developing an awareness of the extent to which involvement with terminating of pregnancy shape their existence. This provokes in the advanced psychiatric nurse practitioners, as researchers, a curiosity with regard to alternative versions of whom these nurses might be. This is a curiosity of how things might be otherwise and different, in reconstructing new and different meanings.

The researchers therefore, will follow up on this process and implement support groups within the nurse respondents' particular context. This will then also create the opportunity for further research.

\section{CONCLUSION}

It is important to take cognisance of methodological challenges while conducting, analysing, interpreting, writing up and disseminating qualitative research. Researchers should always bear these challenges in mind to ensure that principles of trustworthiness are followed and adhered to.

In conclusion, Arthur Frank (2000) explicitly states: "The aim is not to explain people's behaviour, but to be able to explain to themselves, ourselves - the socially organised powers in which their/our lives are embedded, into which their and our activities contribute". It is of utmost importance to remember, whatever aim the researcher strives for, the researcher cannot evade the responsibility of forced encountering with suffering and then keeping the specificity of that encounter at the centre of the project, refusing to assimilate that encounter to the extra local. The aim of research is to oppose the censoring of all things that do not "fit" - the perpetual dilemma is how to recognise those things which means writing it without making it fit.

\section{REFERENCES}

Act no. 92 of 1996: Act on the freedom of choice in terminating pregnancy.

BADENHORST, E 1999: Aborsie eis al 60 000. Rapport, 7 Februarie, p. 13.

Anoniem 1997: Reproductive Rights Alliance, Barometer, 1(2).

BOTES, A 1992: Model vir kwalitatiewe navorsing in 
Verpleegkunde. Curationis, 15(4), 1992:36-42.

BURNS, N \& GROVE, SK 1993. The practice of nursing in research. Philadelphia: WB Saunders.

CRESWELL, JW 1994: Research design: qualitative and quantitative approaches. California, London, New Delhi: Sage Publications.

DEMOCRATIC NURSING ORGANISATION OF SOUTH AFRICA 1998: Ethical measures in research. Pretoria: DENOSA.

FRANK, A 2000: Can we "research" suffering. Keynote address. 6th Annual Qualitative Health Research Conference. Banff, Canada. 6-8 April. 2000.

GMEINER, AC; VAN WYK, S; POGGENPOEL, M \& MYBURGH, CPH 1999: Support for nurses directly involved with women who chose to terminate a pregnancy. Hunter Valley Midwifes Association Journal, 7(4), 1999:24-30.

GMEINER, AC; VAN WYK, S; POGGENPOEL, M \& MYBURGH, CPH 2000: Support for nurses directly involved with women who chose to terminate a pregnancy. Curationis. March 2000.

KVALE, S 1996: Interviews: An introduction to qualitative research interviewing. London: Sage.

MORSE, JM 1999: Researching illness and injury: Methodological considerations. Keynote address delivered at the Fifth International Qualitative Health Research Conference, at Newcastle University, Newcastle, Australia. 10 April 1999.

MORSE, JM \& FIELD, PA 1996: Nursing research. London: Chapman \& Hall.

MORSE, JM \& MITCHAM, C 1997: Compathy: The contagion of physical distress. Journal of Advanced Nursing, 26:649-657.

MORSE, JM; MITCHAM, C \& VAN DER STEEN, V 1998: Compathy or physical empathy: Implications for the caregiver relationship. Journal of Humanities medical, 19(1):52-65.

POGGENPOEL, M \& MYBURGH, CPH 2000: Methodological issues involved with conducting qualitative research on women's experience of terminating a pregnancy. Unpublished paper delivered at Banff. Canada, QHR - 6-8 April 2000.

POGGENPOEL, M; GMEINER, AC \& MYBURGH, CPH 1998: One voice regarding the legalisation of abor- tion: nurses who experience discomfort. Curationis, 21(3):2-8.

WILSON, HS 1989: Research in nursing; 2nd edition. Redwood City, California: Addison-Wesley. 